\title{
Improving the Ability to Write Fantasy Stories and Motivation of Junior High School Students in Writing Fantasy Stories by Using the Discovery Learning Method Assisted by Animated Films
}

\author{
W Wikanengsih* \\ Institut Keguruan dan Ilmu Pendidikan Siliwangi \\ Cimahi, Jawa Barat, Indonesia \\ wikanengsih@ikipsiliwangi.ac.id
}

\author{
Irma Silviani \\ SMP Negeri 8 Purwakarta \\ Purwakarta, Indonesia \\ delta.irmasilviasi@gmail.com
}

\begin{abstract}
This study has four purposes and the first determines the improved ability of junior high school students to write fantasy stories, while the second observes their learning motivation. The third purpose was to identify the relationship between these two aspects, while the fourth observed the difficulties experienced in composing these stories. All the assessments employed discovery learning, which was assisted by animated film media and compared with conventional methods. Meanwhile, the study used a quasi-experimental method with a nonequivalent pretest-posttest control group design. The population comprised seventh-grade students of SMP Negeri in Purwakarta for the 2019/2020 school year. Furthermore, the samples were taken from random subjects, while the instrument included a test, which evaluated the ability to write fantasy stories, and a non-test, which was a student learning motivation questionnaire. The conclusion was based on the research results and data analysis of the two-gain difference tests and n-gain. It revealed that the ability of junior high school students to write fantasy stories using discovery learning methods assisted by animation film media was better than with conventional methods. Also, the motivation that employed the discovery of learning assisted by animated film media was more enhanced than conventional methods. Therefore, a positive relationship exists between learning motivation and writing fantasy stories for these students. The difficulties experienced when writing these stories concerned the knowledge aspect and entailed answering questions about the purpose and summarizing the contents of the narrative text.
\end{abstract}

Keywords—writing fantasy story, learning motivation; discovery learning, and animation film media.

\section{INTRODUCTION}

Writing is a complex language skill that should be included in the curriculum and mastered by students. An example is writing fantasy stories, of which the basic competencies for this ability are to present creative ideas orally as imaginary stories and write with attention to language use and structure. Having the ability to write fantasy stories can train students in critical thinking and creative thinking. Past research has reported that students learn even better when learning from fantasy stories than when learning from real stories [1], [2]

According to Effendy [3], the importance of writing skills includes conveying thoughts, feelings, or considerations through stories. The tool is a language consisting of words, phrases, clauses, sentences, paragraphs, and discourses. Also, the words should be arranged regularly in clauses and sentences to enable people to understand the meaning. The more regularly a language used, the easier it is for people to grasp the thoughts it conveys. [4] also stated that writing is an activity related to one's reasoning. Since thinking and reasoning are manifestations of a person's cognitive style [3], writing reflects this style. Furthermore, an article reveals the critical nature of the author [5].

Encouragement for each individual that has a relationship with learning activities allows the maximal achievement of associated objectives hence, a person with a desire to learn will be successful at it. This desire or encouragement is called motivation and is an internal process that activates guides, and maintains behavior over time [6]. [7] suggested that motivation is an inner part of a situation that causes a person to act in a clear way to fulfill certain goals. According to [8], it is the tendency to improve to produce one or more results. Therefore, motivation is an impulse arising from within a person to improve obtained results and is also a phenomenon that is involved in stimulating action towards certain goals that previously had little or no movement.

Based on the observation results, students encounter difficulty in writing fantasy stories, which occurs because the text requires them to be skilled at creatively telling stories with good flow. The publication of books for students and teachers facilitated by the government as a guideline has not been able to hone their writing skills due to limited text examples and exercises. Although imagination is part of a cognitive process that has a big role in learning, students are less creative in developing story ideas in their imagination and thoughts. Vygotsky [9] argued that imagination as the basis of all creative activities is part of the cognitive process that plays a role in all aspects of life. Therefore, fantasy stories are very important to develop creativity while learning guides students to practice their writing skills and also hone their imaginative creations.

The results of the research conducted by [10] reported that learning to write fantasy stories was suboptimal due to limitations in the process and the difficulty experienced by teachers in promoting motivation. Also, [3] suggested that in the learning process, students paid attention to writing fantasy stories for only $40 \%$ of the available time. Another factor influencing students' success in writing, according to [11] was motivation as it tended to make students pay full attention to the activities being performed. Student motivation needs to be 
built to provoke the generation of creative ideas when writing, and an appropriate learning method is needed to train them to think more imaginatively. [12] argued that optimizing students' potential for creativity through learning was very important and that it was achievable through the use of learning methods. Also, [13] emphasized that the procurement of an attractive learning model must prioritize the concept. [14] explained that the quality of the learning process must be continuously improved, both in the material content and in the method. Since the teacher plays an enormous role in improving the quality of the content and delivery, various strategies and aids can be applied or utilized to achieve and discover effective learning activities.

Based on the description above, it was concluded that the teacher is the most important element for developing student creativity and must be able to choose a learning model that can stimulate and motivate students for this purpose. An example of an applicable model is the discovery learning method, through which teacher-engineered problems are given to students. This is the reason behind the selection of discovery learning methods in defense of writing the text of this fantasy story. This method enables students to exert all their thoughts and skills into obtaining answers for these problems through the research process [15]. Previous research using the discovery learning method was conducted by [16], and the results showed that an increase in student ability and learning motivation was obtained after using the model. Likewise, a study was conducted by [17] in learning to write texts and imaginary stories. To further motivate students, the discovery learning methods can be supported by audio-visual media, such as animated film footage, which encourages students to create imaginatively. This is the research novelty as combining the discovery method with animated films to learn how to write fantasy stories was not found in previous studies.

\section{MethodS}

The research used a quasi-experiment method, and the subjects were randomly selected from eleven existing classes. Two parallel classes were created, which were experiment and control, which both employed the discovery learning method, while the experimental group was assisted by animated film media. The two classes were given a pretest before treatment and a final posttest after. Hence, the design was as follows.

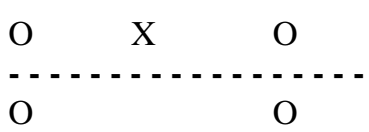

Description:

O: Pretest $=$ Posttest of the students' ability to write fantasy text and their motivation to learn.

$\mathrm{X}$ : Learning using the discovery learning method assisted by animated film media.

- - - : Subjects were not randomly sampled [18].

The population in this study were all junior high school students of the 2019/2020 school year in Purwakarta Regency. Meanwhile, the sample subjects were students in grade seven (VII), where class VII A was taken randomly as an experimental class and treated with discovery learning methods assisted by animation film media. Conversely, class VII B was the control class and treated via the discovery learning method only. This technique was used to determine the sample because the population was assumed to be normally and homogenously distributed. Other considerations in the sampling were the acquisition of student material based on the same curriculum and ensuring that there was no superior class when selecting the research object.

Two types of instruments were used in the study, which was tests to measure the ability to write fantasy stories, and non-test to assess the students' learning motivation. The instrument utilized was ten (10) multiple-choice questions to measure their knowledge, while one question evaluated their performance in writing these stories and employed a scoring rubric. Meanwhile, the non-test instrument was a choice scale where students selected the criteria according to their feelings. The instrument was previously consulted with a related expert to ensure content validity, then tested on seventh-grade students at the same school to confirm empirical validity. Furthermore, the tests were implemented in two stages, where the first was a pretest conducted before the treatment to determine students' abilities and was used as the initial research data. The second stage was the posttest performed after the treatment and was aimed at attaining an increase in the ability to write fantasy stories. Consequently, the data obtained from the test results were processed and given scores for each student's answer according to the answer key and guidelines used. Further data processing was performed using SPSS 22.

\section{RESULTS AND DISCUSSION}

\section{A. Results}

\section{Ability to Write Fantasy Stories (AWFS).}

The description of the students' ability and achievement in writing fantasy stories is shown in Table I. Meanwhile, the data was discovered to be not normally distributed after assessment for normality hence, the Mann Whitney test was used to analyze the average ability. 


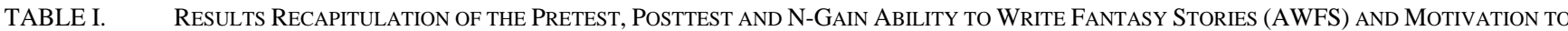
LEARN (ML)

\begin{tabular}{|c|c|c|c|c|c|c|c|c|c|c|}
\hline \multirow[t]{2}{*}{ No } & \multirow[t]{2}{*}{ Ability Type } & \multirow[t]{2}{*}{$\mathbf{n}$} & \multirow[t]{2}{*}{$\begin{array}{l}\text { Ideal } \\
\text { Score }\end{array}$} & \multirow[t]{2}{*}{ Statistics } & \multicolumn{3}{|c|}{$\begin{array}{l}\text { Discovery Learning Assisted by } \\
\text { Animation Film }\end{array}$} & \multicolumn{3}{|c|}{ Conventional } \\
\hline & & & & & Pretest & Posttest & $\mathrm{N}$-gain & Pretest & Posttest & $\mathrm{N}$-gain \\
\hline \multirow[t]{3}{*}{1.} & \multirow[t]{3}{*}{ AWFS } & \multirow[t]{3}{*}{30} & \multirow[t]{3}{*}{100} & & 76 & 83 & \multirow[t]{2}{*}{0.29} & 74 & 78 & \multirow[t]{2}{*}{0.15} \\
\hline & & & & $\%$ & $76 \%$ & $83 \%$ & & $74 \%$ & $78 \%$ & \\
\hline & & & & SD & 2.97 & 7.77 & & 3.19 & 5.94 & \\
\hline \multirow[t]{2}{*}{2.} & \multirow[t]{2}{*}{ ML } & \multirow[t]{2}{*}{30} & \multirow[t]{2}{*}{120} & & 86 & 110 & \multirow[t]{2}{*}{0.70} & 84 & 92 & \multirow[t]{2}{*}{0.22} \\
\hline & & & & $\%$ & $72 \%$ & $92 \%$ & & $70 \%$ & $77 \%$ & \\
\hline
\end{tabular}

TABLE II. HYPOTHESIS TEST OF AWFS AND ML

\begin{tabular}{|l|l|l|l|l|l|l|}
\hline Variable & Learning approaches & Posttest & SD & N & Sig & Interpretation \\
\hline \multirow{2}{*}{ AWFS } & PBL assisted by Animated Film & 83 & 78 & 7.77 & 30 & 0.00 \\
\cline { 2 - 5 } & Conventional & $\begin{array}{l}\text { The AWFS of the experimental class } \\
\text { students was better than the control class. }\end{array}$ \\
\hline ML & PBL assisted by Animated Film & 110 & 15.837 & 30 & $\begin{array}{c}\text { The ML of the experimental class } \\
\text { students was better than the control class. }\end{array}$ \\
\hline
\end{tabular}

Note: AWFS ideal score: 100, ML ideal score: 120

Keep your text and graphic files separate until after the text has been formatted and styled. Do not use hard tabs, and limit use of hard returns to only one return at the end of a paragraph. Do not add any kind of pagination anywhere in the paper. Do not number text heads-the template will do that for you. Based on the data in Table I regarding the recapitulation of pretest and posttest results, as well as the hypothesis outcomes in Table II, the following findings were produced:

The initial ability of both classes was at a moderate level, as $76 \%$ and $74 \%$ were obtained as the ideal scores for the experimental and control class, respectively. However, the final results were at a high level for the experimental group, attaining $83 \%$ of the ideal value, while the control class was at a moderate level and obtained $78 \%$ of the ideal score. Therefore, the N-gain students 'ability in writing fantasy stories was better in the experimental class than in the control group.

\section{Motivation to Learn (ML)}

Table I also shows that the students learning motivation in both groups were at a moderate level at the pretest time, particularly at $72 \%$ and $70 \%$ for the experimental and control classes, respectively. However, the final test results of the experimental class were larger at $92 \%$ compared to the control class, which produced a score of $77 \%$.

\section{Association between AWFS and ML}

The association between AWFS and ML was analyzed using contingency tables, as in Tables III and IV. This study proves that although there is an association or relationship between AWFS and ML, they do not influence each other. The data in Table III showed that students with low AWFS are associated with reduced ML as well, and students with moderate AWFS moderate ML. This also applies to students with high AWFS and ML.

TABLE III. ASSOCIATION BETWEEN AWFS AND DISCOVERY LEARNING (DL) IN ANIMATED MEDIA ASSISTED PBL CLASSROOM

\begin{tabular}{|l|l|l|l|l|}
\hline \multirow{2}{*}{ AWFS } & \multicolumn{3}{|c|}{ ML } & \multirow{2}{*}{ Total } \\
\cline { 2 - 4 } & Low & Moderate & High & \\
\hline Low & 8 & 0 & 0 & 8 \\
\hline Moderate & 0 & 13 & 0 & 13 \\
\hline High & 0 & 0 & 9 & 9 \\
\hline
\end{tabular}

TABLE IV. ASSOCIATION TEST RESUlt BETWEEN AWFS AND ML

\begin{tabular}{|l|l|l|l|}
\hline $\begin{array}{l}\text { Learning } \\
\text { Ability and } \\
\text { Motivation }\end{array}$ & $\begin{array}{l}\text { Contingency } \\
\text { Coefficient }\end{array}$ & Sig & Interpretation \\
\hline AWFS and ML & .816 & .000 & $\begin{array}{l}\text { There is a } \\
\text { considerable } \\
\text { association at the 5\% } \\
\text { significance level }\end{array}$ \\
\hline
\end{tabular}

\section{Student Difficulties in Writing Fantasy Stories}

The values of the students' ability to write fantasy stories for each aspect is shown in Figure 1. 


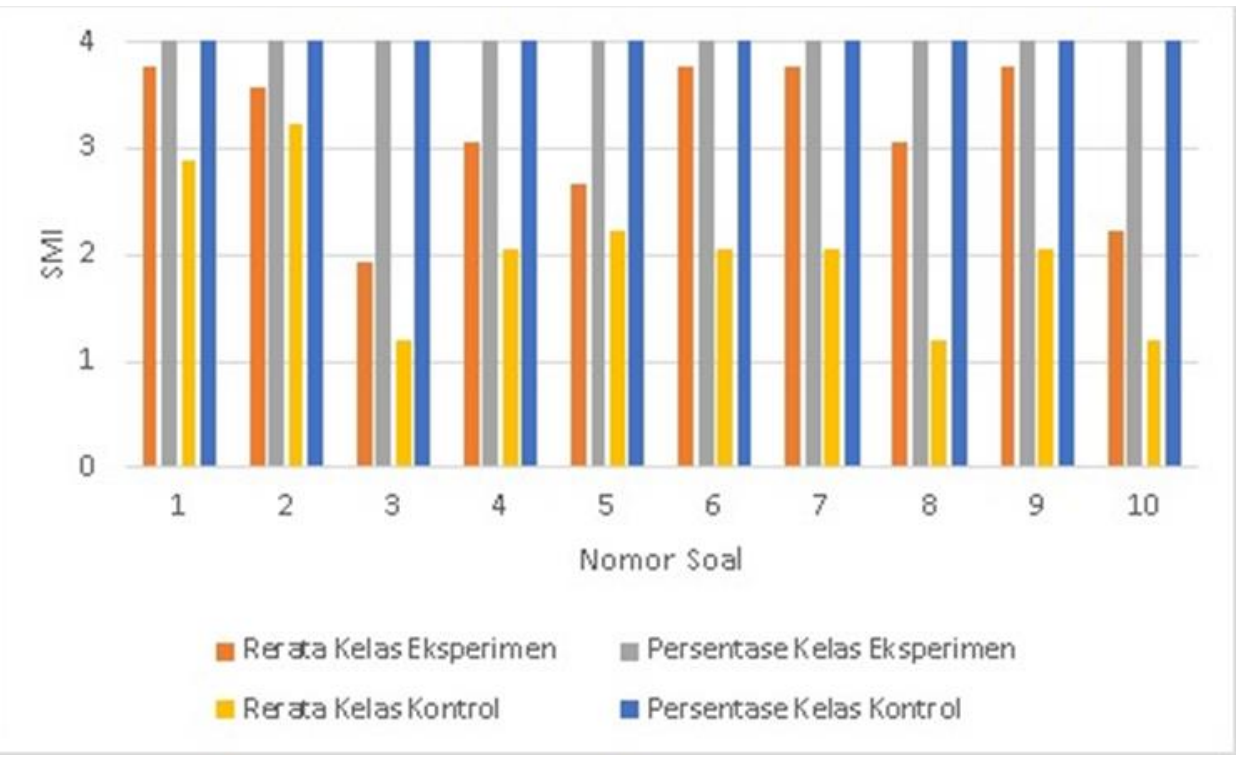

Fig. 1. The Score of Each AWFS Aspect on Conventional Learning and the Discovery Method Assisted by Animated Films

The percentage of the SMI score was used to determine the difficulties experienced by students in solving the final posttest questions in the experimental and control classes. This evaluation was performed by comparing the score of the total SMI value per question item multiplied by 100 with the criteria:

a) If the percentage of the SMI score is greater than $65 \%$, then the students had no difficulty in solving the questions.

b) If the percentage score is less than $65 \%$, then the students encountered difficulties in solving the questions.

Based on Table $\mathrm{V}$ above, the SMI scores for numbers 3 and 10 for the students in the experimental class were below $65 \%$. Hence, the students experienced difficulties with both questions. Question 3 entailed the writing purpose of a fantasy story, while number 10 involved a summary of the text. Meanwhile, the students in the control class had achievements below $65 \%$ for questions $3,4,5,6,7,8,9$, and 10 . Therefore, they encountered difficulties in answering the eight questions, while numbers 3 and 10 intersected for the two classes studied.

\section{B. Discussion}

\section{Ability to Write Fantasy Stories (AWFS)}

The results showed that the AWFS of the students in the experimental class was better than the control group's writing skills after the implementation of the discovery learning method assisted by animated films. This was proven by the data of pretest results of 76 to 83 in posttest results in the experiment class, while in the control class the results of pretest 74 and postest 78 results. There are increasing differences between experimental classes and control classes. The students in the experiment class seemed more excited when learning when compared to the control class. These findings illustrate the superior impact of the discovery learning method, as stated by [19]. According to this researcher, this method can increase students' learning enthusiasm and skills in cognitive processing, develop their abilities, motivation, and self-confidence. This finding also corresponds with the research results from [20], [17]; [8]; [21]; [22]. The outcomes of all these studies showed that students' writing skills in the experimental class were better than those in the control group.

\section{Motivation to learn}

There was an increase in the learning motivation of the experimental class after the implementation of the discovery method assisted by animated films. This increase was due to the steps taken by the model to create a comfortable learning atmosphere by the use of the animated film screening. [8] suggested that students' learning motivation can be triggered by comfortable classroom conditions, a close relationship between friends, and a pleasant attitude of the teacher towards students. This finding is similar to the results by [23], [24]; [25]. The outcomes stated that there was a difference in motivation between the experimental and control class after the implementation of the discovery learning method.

\section{Association between AWFS and ML}

The association between AWFSA and ML students in this study is similar to the research of [26]; (Adeninawaty1 \& Ridhani, 2018) on the ability to write review texts. Consequently, the findings of the association between skills in writing fantasy stories with learning motivation were consistent, including for the students' abilities classified as high, medium, and low.

\section{Student Difficulties in Writing Fantasy Stories}

The findings proved that students in both classes were unable to understand the purpose of writing fantasy texts and were less skilled at composing the summary stories. This outcome contradicts the results of the studies by [28] and [29]. According to the research by Febrianti \& Thahar, the ability of students to write descriptive texts for fictional fantasy stories was better because it availed them the freedom to express their ideas into the story, unlike when the text was nonfiction. Therefore, further research is needed to determine the factors that caused these differences between this research results with previous studies. 


\section{CONCLUSION}

This research produced several conclusions, which include the classification of the students' ability and motivation in writing fantasy stories with the discovery learning method as very good and as better than the conventional class, which was classified as moderate. The students' motivation in the experimental class was also better than those in the control group. Furthermore, a non-mutually occurring association was discovered between the ability to write fantasy stories and student motivation. Finally, students were noted to experience difficulties in writing fantasy stories concerning the knowledge aspect, particularly in understanding the purpose and content summary.

\section{ACKNOWLEDGMENT}

The authors are grateful to the Indonesian language teachers and Principal of SMPN 8 Purwakarta for supporting the research implementation. The authors are also grateful to the Rector of the IKIP Siliwangi for continuously rendering motivation and promoting enthusiasm in performing the Tridarma of Higher Education.

\section{REFERENCES}

[1] E. J. Hopkins and D. S. Weisberg, "Investigating the effectiveness of fantasy stories for teaching scientific principles," J. Exp. Child Psychol., vol. 203, p. Manuscript accepted for publication, 2020.

[2] A. P. Vidal, "Multimodality and Fantasy and Stories in University Teacher Training1," Procedia - Soc. Behav. Sci., vol. 178, no. November 2014, pp. 190-195, 2015

[3] A. Effendy, Hakikat keterampilan menulis. [Online]. Diakses dari http://bahasa.kompasiana.com/2012/03/25/hakikat-keterampilanmenulis-. 2012.

[4] W. Wikanengsih, "Model Pembelajaran Neurolinguistic Programming Berorientasi Karakter Bagi Peningkatan Kemampuan Menulis Siswa SMP,” J. Ilmu Pendidik. Univ. Negeri Malang, vol. 19, no. 2, p. 104445, 2013.

[5] A. Syaifudin, "Penalaran Argumen Siswa Dalam Wacana Tulis Argumentatif Sebagai Upaya Membudayakan Berpikir Kritis Di Sma," Ling. J. Bhs. dan Sastra, vol. 7, no. 1, pp. 65-76, 2011.

[6] S. B. Sjukur, "Pengaruh blended learning terhadap motivasi belajar dan hasil belajar siswa di tingkat SMK," J. Pendidik. Vokasi, vol. 2, no. 3, pp. 368-378, 2013.

[7] M. Cleopatra, "Pengaruh Gaya Hidup dan Motivasi Belajar terhadap Prestasi Belajar Matematika," Form. J. Ilm. Pendidik. MIPA, vol. 5, no. 2, pp. 168-181, 2015.

[8] S. Yanti, E. Erlamsyah, and Z. Zikra, "Hubungan antara Kecemasan dalam Belajar dengan Motivasi Belajar Siswa," Konselor, vol. 2, no. 1, pp. 283-288, 2013 .

[9] D. Yusmaliana and S. Suyadi, "Pengembangan Imajinasi Kreatif Berbasis Neurosains dalam Pembelajaran Keagamaan Islam," Edukasia J. Penelit. Pendidik. Islam, vol. 14, no. 2, p. 267, 2019.

[10] N. K. N. N. Pande and N. Artana, "Kajian Pragmatik Mengenai Tindak Tutur Bahasa Indonesia Dalam Unggahan Media Sosial Instagram @ halostiki,” Alf. J. Bahasa, Sastra, dan Pembelajarannya, vol. 3, no. 1, pp. 32-38, 2020.

[11] N. Zuliawati, "Pengaruh Kreativitas dan Motivasi Kerja terhadap Produktivitas Guru Pendidikan Agama Islam Sekolah Dasar
Sekecamatan Baturetno Kabupaten Wonogiri," At-Tarbawi J. Kaji. Kependidikan Islam, vol. 1, no. 1, p. 23, 2016.

[12] Momon Sudarma, Mengembangkan Keterampilan Berfikir Kreatif. 2013.

[13] Ansori, "Peningkatan Kemampuan Menulis Mahasiswa Melalui Model Workshop Dalam Perkuliahan Kepenulisan Pada Program Nonkependidikan Jurusan Pendidikan Bahasa," J. Chem. Inf. Model., vol. 110, no. 9, pp. 1689-1699, 2017.

[14] R. Y. Purwoko, "Urgensi Pedagogical Content Knowledge dalam Meningkatkan Kualitas Pembelajaran Matematika," J. Pendidik. Surya Edukasi, vol. 3, no. 2, pp. 42-55, 2017.

[15] Kemendikbud, Metode Saintific dalam Pembelajaran. Jakarta: Pusbangprodik, 2013.

[16] S. W. Bagja and D. Yuliana, "Penerapan Model Pembelajaran Discovery Learning Meningkatkan Motivasi dan Hasil Belajar Pendidikan Kewarganegaraan 1," J. Rontal Keilmuan PKn, vol. 5, no. 1, pp. 17-30, 2019.

[17] N. Silvana, I. Basri, and Emidar, "Pengaruh Model Discovery Learning Terhadap Keterampilan Menulis Teks Cerita Fantasi Siswa Kelas VII SMP Negeri 10 Padang," J. Pendidik. Bhs. dan Sastra Indones., vol. 7, no. 4, pp. 76-82, 2018.

[18] E. T. Ruseffendi, Dasar - Dasar Penelitian Pendidikan dan Bidang Non Eksakta Lainnya. Bandung: Tarsito, 2010.

[19] Roestiyah, Strategi Belaajr Mengajar. Jakarta: Rineka Cipta, 2012.

[20] H. Azkiya and R. Isnandab, "Pengaruh Model Pembelajaran Discovery Learning Terhadap Keterampilan Menulis Teks Eksplanasi Siswa Kelas VII MTSN Durian Tarung Padang," Bahastra, vol. 38, no. 2, p. 95, 2019.

[21] R. Suhada, I. Idrus, and K. Kasrina, "Peningkatan Hasil Belajar Siswa Melalui Penerapan Model Pembelajaran Discovery Learning," Diklabio J. Pendidik. dan Pembelajaran Biol., vol. 3, no. 1, pp. 32-40, 2019.

[22] A. V. Souhuwat, "Peningkatan Keterampilan Menulis Teks Cerita Fantasi Dengan Model Discovery Learning Dan Media Audio Visual Pada Siswa Kelas Vii5 Smp Negeri 3 Ambon,” ARBITRER J. Pendidik. Bhs. dan Sastra Indones., vol. 1, no. 3, pp. 167-178, 2019.

[23] R. H. Putri, A. D. Lesmono, and P. D. Aristya, "Pengaruh model discovery learning terhadap hasil belajar," J. Pembelajaran Fis., vol. 6, no. 2, pp. 168-174, 2017.

[24] Y. Patandung, "Pengaruh model discovery learning terhadap peningkatan motivasi belajar IPA Siswa," J. Educ. Sci. Technol., vol. 3, no. 1, p. 9, 2017.

[25] Margie, "Peningkatan Motivasi Dan Kemampuan Menulis Puisi Melalui Teknik Timlo Aplikasi Copy The Master Peserta Didik Kelas Viii A Smp N 3 Sragi Kabupaten Pekalongan," Transformatika, vol. 1, no. 1, pp. 57-73, 2017.

[26] S. Marliana, "Penerapan Model Pembelajaran Think Talk Write dalam Meningkatkan Hasil Belajar,” J. Elem. Sch., vol. 1, no. 2, pp. 226-236, 2018.

[27] D. Adeninawaty, R. Soe'Oed and A. Ridhani, "Penerapan Model Pembelajaran Discovery Learning Strategi Think Talk Write dalam Meningkatkan Motivasi dan Hasil Belajar Menulis Teks Ulasan Kelas VIII SMP," DIGLOSIA, vol. 1, no. 2, pp. 75-78, 2018.

[28] D. M. Sari, "Komparasi Keterampilan Menulis Teks Eksposisi dengan Keterampilan Menulis Teks Cerpen Siswa Kelas VIII SMP Negeri 33 Padang," 2015.

[29] V. Febrianti and H. E. Thahar, "Komparasi Keterampilan Menulis Teks Deskripsi dengan Keterampilan Menulis Teks Cerita Fantasi Siswa Kelas VII SMP Negeri 7 Padang," Pendidik. Bhs. Indones., vol. 9, no. 2, p. 72,2020 